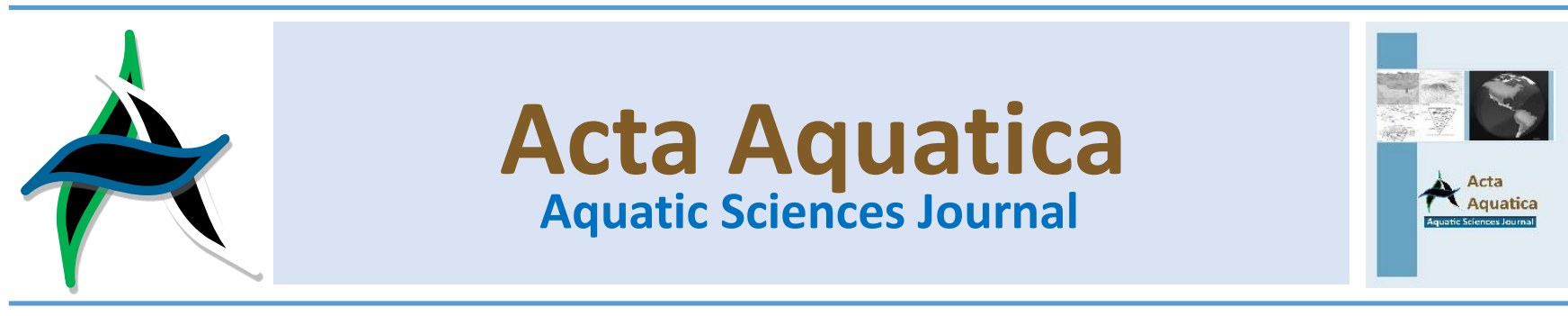

\title{
Effect of freshness grade of anchovy (Engraulis encrasicolus) on the quality of marinated product stored at $4^{\circ} \mathrm{C}$
}

\author{
Nalan Gokoglu a, *, Ilknur Ucak b \\ ${ }^{a}$ Akdeniz University, Faculty of Fisheries Antalya, Turkey \\ ${ }^{b}$ Nigde Omer Halisdemir University, Faculty of Agricultural Sciences and Technologies Nigde, Turkey
}

\begin{abstract}
The aim of this study was to investigate the effects of raw material freshness on the quality of marinated fish. The raw material anchovy (Engraulis encrasicolus) was divided into two batches. One batch $(\mathrm{A})$ was kept at ambient temperature $\left(20^{\circ} \mathrm{C}\right)$ for $6 \mathrm{~h}$ and the other one was kept at $0^{\circ} \mathrm{C}$ for $72 \mathrm{~h}$. Then, they were marinated by soaking into marination solution containing $3 \%$ acetic acid and $8 \% \mathrm{NaCl}$. Total volatile basic nitrogen (TVB-N), trimethylamine (TMA), thiobarbituric acid (TBA), para-anisidine ( $\mathrm{p}-\mathrm{Av}$ ) values in both marinated samples increased significantly during storage at $4^{\circ} \mathrm{C}$. Increases in quality parameters were higher in samples produced with raw anchovy kept at $20^{\circ} \mathrm{C}$ compared to samples kept at $0^{\circ} \mathrm{C}$. Although the sensory scores of both samples decreased during storage, higher scores were obtained for samples kept at $0^{\circ} \mathrm{C}$ compared to samples kept at ambient temperature. According to the results of the study, it has been determined that the quality of the raw material significantly $(p<0.01)$ affects the quality of marinated anchovy.
\end{abstract}

Keywords: fish; quality; anchovy; marinade; raw material

\section{Introduction}

Marinated fish are semi-preserved, ready-to-eat with no heat treatment and are high-value delicatessen fish products (Fuentes et al., 2010). Acetic acid and salt are added to fish to retard the action of bacteria and enzymes. This process results in a product with a characteristic flavor and an extended but limited shelf life (Mc Lay, 1972).

The anchovy (Engraulis encrasicolus), which is a pelagic fish species belonging to the Engraulidae family, is a common material for fish marinades. Generally, filleted anchovies are soaked to a solution containing acetic acid and salt. After ripening, they are packed with vegetable oil or sauce.

Fish and fish products are perishable materials that deteriorate quickly. The easy deterioration of fish quality is because of the post-mortem biological changes that take place in the body of dead fish (Sikorski et al., 1990). Freshness is a major contribution to the quality of seafood products. For all kinds of seafood products, freshness is essential for the quality of the final product (Alasalvar et al., 2010). Considering the properties of raw material such as freshness, microbial load and physical damage, the initial quality is an important factor affecting the end product quality (Fuselli et al., 1994; Capaccioni et al., 2011). It is known that during marination, microbial activity is inhibited due to the combined effect of salt and acid

\footnotetext{
* Corresponding author: Faculty of Fisheries, Akdeniz University, 07058. Antalya, Turkey. FAX: +902422262013

e-mail:ngokoglu@akdeniz.edu.tr

doi: http://doi.org/10.29103/aa.v7i2.2459
}

solutions. It is thought that the marinating process provides food safety with microbial inactivation and therefore, the initial quality of the fish is insignificant.

Based on this wrong thought, this study aimed to investigate the effects of the freshness of the raw material on the quality and storage stability of marinated fish. For this purpose, fish marinade was produced using anchovy in two different freshness grades. Anchovy sometimes exposures to ambient temperature for a few hours before reaching to market or processing plant. In some cases, processors use not only freshly harvested fish but also use refrigerated fish. For this reason, in this study, it was aimed to investigate the effect of freshness grade of anchovy on marinating quality during the storage. For this purpose, the fish were kept at ambient for $6 \mathrm{~h}$ and refrigerated temperatures for $72 \mathrm{~h}$ before marination.

\section{Materials and methods}

\subsection{Material}

The material was anchovy (Engraulis encrasicolus) purchased from the main fish market. The fish boxed with crushed ice were transferred to the laboratory immediately. Upon arrival at the laboratory, the fish were divided into the following batches: (A) This batch was kept at ambient temperature $\left(20^{\circ} \mathrm{C}\right)$ for $6 \mathrm{~h}$; $(\mathrm{B})$ this batch was kept in boxes with ice at $0^{\circ} \mathrm{C}$ for $72 \mathrm{~h}$. The fish ware filleted and washed before the marination process. 


\subsection{Methods}

For the marination process, firstly, marinating brine solutions containing $3 \%$ acetic acid and $8 \% \mathrm{NaCl}$ were prepared. Anchovy fillets were immersed into the brine at $20^{\circ} \mathrm{C}$. The ratio of fish to solution was $1: 1.5$. After $24 \mathrm{~h}$ which ripening was completed, the fish were taken from the solutions and put into the boxes with sunflower oil. Packaged fish was stored at $4^{\circ} \mathrm{C}$ for 4 weeks. During the storage, analyses were done at weekly intervals.

\subsection{Data analysis}

Analyses of the raw samples were made as soon as they arrived at the laboratory. Analyses of samples kept at room temperature and $4^{\circ} \mathrm{C}$ were carried out $6 \mathrm{~h}$ and $72 \mathrm{~h}$, respectively. Analyses of marinated samples were carried out at weekly intervals. Before analyses, marinated fish were removed from the boxes, and drained on filter paper $\left(73 \mathrm{~g} / \mathrm{m}^{2} 40 \times 40 \mathrm{~cm}\right)$ for $10 \mathrm{~min}$ and homogenized using the blender. All analyses were conducted in duplicate samples.

\subsubsection{Total volatile basic nitrogen (TVB-N)}

$10 \mathrm{~g}$ sample was washed into the distillation flask and 1 $\mathrm{mg}$ magnesium oxide was added with a drop or two of silicone anti-foam solution. Samples were boiled and distilled into $10 \mathrm{ml}$ of $0.1 \mathrm{~N} \mathrm{HCl}$ solutions in a $500 \mathrm{ml}$ conical flask with added Tashiro-indicator. After distillation, the contents of conical flask were titrated with $0.1 \mathrm{~N} \mathrm{NaOH}$ (Schormüller, 1968).

\subsubsection{Trimethylamine (TMA-N)}

A $10 \mathrm{~g}$ sample was blended with $90 \mathrm{ml}$ of $5 \%$ trichloroacetic acid (TCA) using an ultra-turrax homogenizer and filtered. A $4 \mathrm{ml}$ aliquot was transferred into test tubes and $1 \mathrm{ml}$ formaldehyde (20\%), $10 \mathrm{ml}$ anhydrous toluene, $3 \mathrm{ml} \mathrm{KOH} \mathrm{(50}$ $\%)$ solution were added. The tubes were shaken, and a $5 \mathrm{ml}$ toluene layer was pipetted to which $5 \mathrm{ml}$ picric acid (0.02\%) had been added. The supernatant was then transferred to a spectrophotometric cell. Absorbance at $410 \mathrm{~nm}$ was measured. At the same time, a series of standards were prepared and measured (Schormüller, 1968).

\subsection{3. $\mathrm{pH}$}

The $\mathrm{pH}$ value was determined by dipping the $\mathrm{pH}$ electrode into homogenates of filleted muscle in distilled water (1/1) (Manthey et al., 1988). All measurements were performed at room temperature using $\mathrm{pH}$-meter (WTW Inolab, Weilhem, Germany).

\subsubsection{Thiobarbituric acid (TBA)}

The thiobarbituric acid (TBA) distillation method was performed as described by Tarladgis et al. (1960). A homogenized $10 \mathrm{~g}$ sample was distilled after the addition of 2.5 $\mathrm{ml} \mathrm{HCl}$ and distilled water solution (1+2). A $5 \mathrm{ml}$ aliquot of the distilled solution was transferred into the stoppered test tube and $5 \mathrm{ml}$ TBA solution ( $0.288 \mathrm{~g}$ TBA $/ 100 \mathrm{ml}$ distilled water) was added. The test tube was shaken and was left in a water bath at $110^{\circ} \mathrm{C}$ for $35 \mathrm{~min}$. The absorbance was determined by a spectrophotometer (Shimadzu UV 160A, Tokyo, Japan) at 538 $\mathrm{nm}$ against a blank containing distilled water and TBA solution. The results were expressed as milligrams of malonaldehyde per kilogram of fish flesh.

\subsubsection{Para-anisidine value ( $p-A v)$}

Para-anisidine value was determined by the IUPAC method (1987). $0.5 \mathrm{~g}$ of fish lipid was dissolved in $25 \mathrm{ml} \mathrm{n}$ hexane and absorbance of the mixture was measured at $350 \mathrm{~nm}$ using a UV-Vis spectrophotometer $\left(A_{1}\right)$. Para-anisidine reagent was added to $5 \mathrm{ml}$ of the mixture and held in the dark for 10 minutes before absorbance reading $\left(A_{2}\right)$ at the same wavelength. Value of $\mathrm{p}-\mathrm{Av}$ was calculated using the following:

$$
p-A v=25\left(1.2 \times\left(A_{2}-A_{1}\right)\right) / \text { sample weight }
$$

\subsubsection{Sensory analysis}

Sensory analysis was performed by a panel of 5 panellists. The panellists were from the staff of the Fish Processing Department, who had experience evaluating seafood. The panellists evaluated the samples for odour, appearance, taste and texture on a 9-point hedonic scale (Amerina et al., 1965) and overall acceptability was calculated. A score of 9-7 indicated "very good", a score of 6.9-4.0 "good", a score of 3.9-1.0 denoted as spoiled.

\subsubsection{Microbiological analyses}

For microbiological analysis, a $10 \mathrm{~g}$ sample was added to $90 \mathrm{ml}$ of sterile ringer solution and homogenized in a stomacher (Stomacher 80, Seward Medical, and London, UK) for 2 min at low speed at room temperature. Serial decimal dilutions were made and plated onto appropriate culture media (Anonymous, 1992). Aerobic mesophilic counts (APC) were determined by the spread plate method on Plate Count Agar. Plates were incubated at $37^{\circ} \mathrm{C}$ for $48 \mathrm{~h}$ under aerobic conditions. Psychotropic counts were determined by the spread plate method on Plate Count Agar. Plates were incubated at $4^{\circ} \mathrm{C}$ for 7 days (Anonymous, 1992). E. coli was examined by the spread plate method on Violet Red Bile Agar (VRBA). Then overlaid with VRB-MUG and allowed to solidify, then incubated at $37^{\circ} \mathrm{C}$ for 24 h. These plates were examined under long-wavelength UV lamb for the presence of fluorescent colonies (Anonymous, 1992). Fluorescent colonies were enumerated as E. coli. Yeast-molds were enumerated with Potato Dextrose Agar. Petri dishes were incubated at $25^{\circ} \mathrm{C}$ for 5 days for yeast-mold (Anonymous, 1992). All microbial counts were expressed as base-10 logarithms of colony forming units per gram (log CFU/g).

\subsubsection{Statistical analysis}

Two replications of the experiment were conducted at separate times and all analyses were performed in duplicates. Data were subjected to analysis of variance followed by Duncan's Multiple Range Test using the SAS software (Statistical Analysis System, Cary, NC, USA).

\section{Result and discussion}

TVB-N value of anchovy was found to be $14.68 \mathrm{mg} / 100 \mathrm{~g}$ immediately after arrival at the laboratory. TVB-N value of sample (A) kept at ambient temperature was found to be 18.81 $\mathrm{mg} / 100 \mathrm{~g}$ after $6 \mathrm{~h}$. TVB- $\mathrm{N}$ value of sample (B) kept at $0^{\circ} \mathrm{C}$ was $14.66 \mathrm{mg} / 100 \mathrm{~g}$ after $72 \mathrm{~h}$. While there were significant $(p<0.01)$ differences in TVB-N values of anchovy samples after keeping at $20^{\circ} \mathrm{C}$ for $6 \mathrm{~h}$, no differences were observed in samples kept at $0^{\circ} \mathrm{C}$ for $72 \mathrm{~h}$. Lower TVB-N values were observed after marination compared to raw samples. The ripening process of marinated fish was completed in $24 \mathrm{~h}$. 
After ripening, TVB- $N$ values of samples $A$ and $B$ were found to be 14.48 and $10.47 \mathrm{mg} / 100 \mathrm{~g}$, respectively. Similar decreases were reported after marinating process by Maktabi et al. (2015) and Pons-Sanchez-Cascado et al. (2015). TVB-N values of marinated anchovy produced from both raw samples significantly increased during storage at $4^{\circ} \mathrm{C}$. Similar increases in storage were reported in previous studies (Aksu et al., 1997; Gokoglu et al., 2004; Gokoglu et al., 2009; Maktabi et al. 2015). TVB-N values of sample B were lower compared to sample A. The TVB-N values of both samples did not reach critical values after 4 weeks of storage (Fig. 1). The level of 30-35 mg TVB$\mathrm{N} / 100 \mathrm{~g}$ has been reported as an acceptable upper limit for seafood (Ludorf \& Meyer, 1973; Sikorski et al., 1990). The TVB-N value has been reported to be more useful in assessing the degree of sardine deterioration than evaluating changes in the initial stages of storage (El Marrackhi et al., 1990).

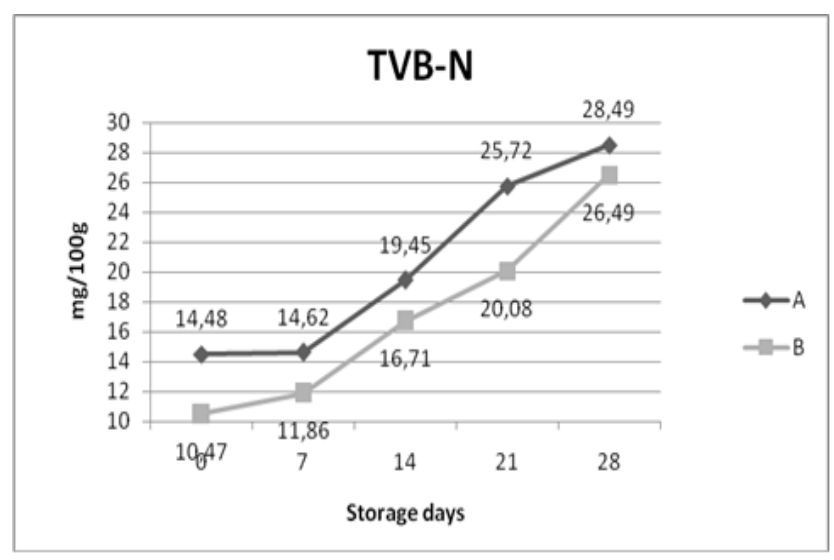

Figure 1. Total volatile basic nitrogen (TVB-N) values of marinated samples A (kept at $20^{\circ} \mathrm{C}$ ) and $\mathrm{B}\left(\right.$ kept at $0^{\circ} \mathrm{C}$ ) during refrigerated storage

The TMA-N value of anchovy was found as 0.022 $\mathrm{mg} / 100 \mathrm{~g}$ immediately after arrival at the laboratory. Significant $(p<0.01)$ differences in TMA-N values of anchovy were found after keeping at $20^{\circ} \mathrm{C}$ for $6 \mathrm{~h}$ and at $0^{\circ} \mathrm{C}$ for $72 \mathrm{~h}$. TMA-N value of samples kept at $20^{\circ} \mathrm{C}$ was found to be $0.415 \pm 0.099 \mathrm{mg} / 100 \mathrm{~g}$ after $6 \mathrm{~h}$. TVB-N value of samples kept on ice was $0.25 \pm 0.071$ $\mathrm{mg} / 100 \mathrm{~g}$ after $72 \mathrm{~h}$. TMA- $\mathrm{N}$ values of $A$ and $B$ samples were not statistically different from the value of raw fish statistically $(p>0.01)$. Significant $(p<0.01)$ increases in TMA-N values were found after marinating. TMA-N values of both samples increased significantly during storage (Fig. 2).

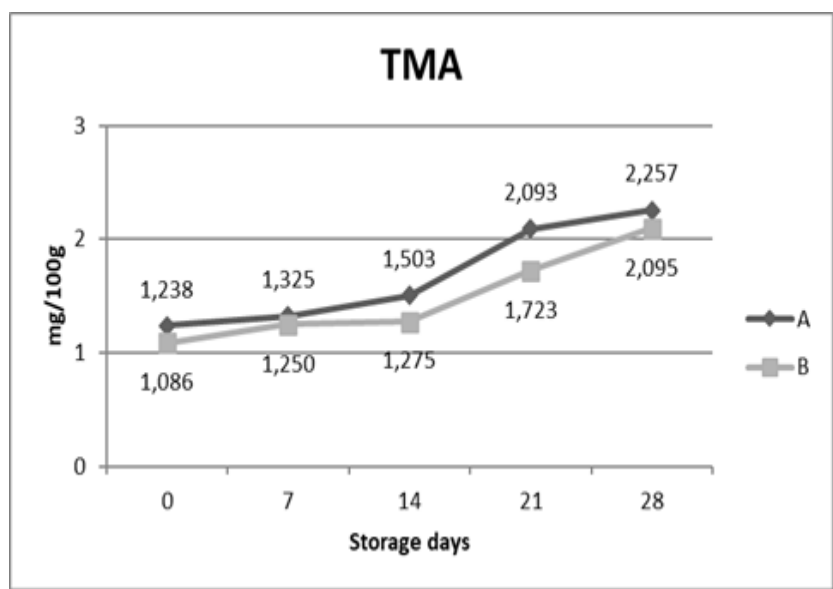

Figure 2. Trimethylamine (TMA) values of marinated samples $A$ (kept at $20^{\circ} \mathrm{C}$ ) and $\mathrm{B}\left(\right.$ kept at $0^{\circ} \mathrm{C}$ ) during refrigerated storage
This increase was very slow in the early stages of storage. The increase in TMA-N values was faster after 14 days. On the 28th day of storage, TMA-N values reached 2.25 and $2.09 \mathrm{mg} / 100 \mathrm{~g}$ in samples $A$ and $B$, respectively. In previous studies, similar increases have been reported during refrigerated storage (Ozden \& Baygar, 2003; Gokoglu et al., 2004; Sallam et al., 2007). TMA-N values did not exceed acceptable limit values during 4 weeks of storage. TMA value of $5-10 \mathrm{mg} / 100 \mathrm{~g}$ sample was reported as the acceptability limit of the fish (Sikorski et al., 1990). TMA-N results from the reduction of TMA-N oxide by bacterial activity and partly by intrinsic enzymes and is often used as an index of the freshness of marine fish (Villareal \& Pozo, 1990). In this study, raw material quality affected TMA-N values during storage. Lower TMA-N values were found in marinated fish produced using more fresh raw materials.

The mean $\mathrm{pH}$ value of the samples just after arrival at the laboratory was measured as $6.90 \pm 0.02$. The values did not change significantly after keeping at $20^{\circ} \mathrm{C}$ and $0^{\circ} \mathrm{C}$. However, after marination, significant decreases were found due to acetic acid penetration into the fish muscle. Similar decreases were reported in previous studies (Sen \& Temelli, 2003; Gokoglu et al., 2004; Maktabi et al., 2015). The pH values of both sample (A and $B$ ) significantly $(p<0.01)$ increased during the storage (Fig. 3 ). At the first 7 days of storage, sharply increase was observed. Increases in $\mathrm{pH}$ values of the samples occurred slowly on other storage days. At the end of storage, $\mathrm{pH}$ values of sample $\mathrm{A}$ and $B$ reached 4.41 and 4.34 , respectively. During the storage of marinades, heterofermentative lactic acid bacteria can grow and cause the breakdown of amino acids. Thus, the formation of carbon dioxide and other decarboxylation products is observed. These products bind acetic acid and the $\mathrm{pH}$ of the marinade rises (Shenderyuk \& Bykowski, 1989).

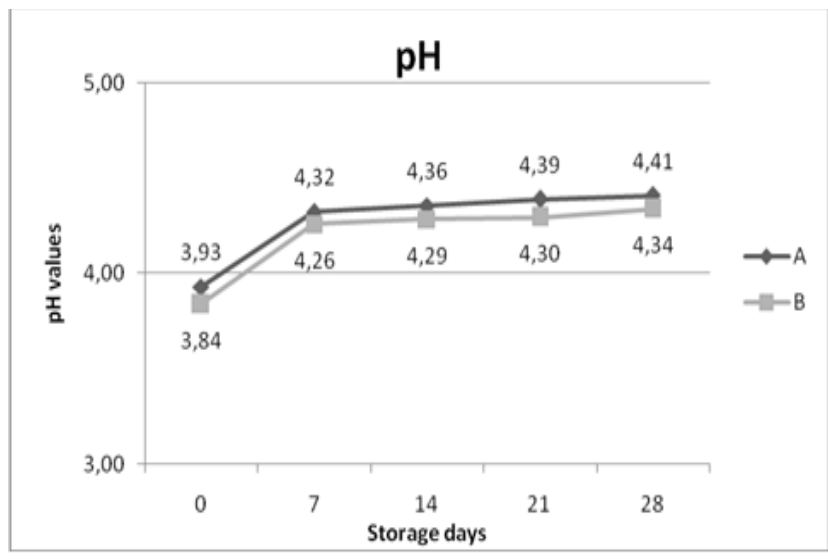

Figure 3. $\mathrm{pH}$ values of marinated samples $\mathrm{A}$ (kept at $20^{\circ} \mathrm{C}$ ) and $\mathrm{B}$ (kept at $0^{\circ} \mathrm{C}$ ) during refrigerated storage

The initial TBA value of the raw material was 2.12 $\mathrm{mg} / \mathrm{kg}$. It was observed that the TBA values of raw materials did not change significantly after $6 \mathrm{~h}$ at $20^{\circ} \mathrm{C}$ and $72 \mathrm{~h}$ at $0^{\circ} \mathrm{C}$. After marination, significant decreases were found in the TBA values of both samples. TBA analysis is an important quality index indicating fat oxidation. Oxidative rancidity is complex spoilage and especially occurs in fatty fishes (Connell, 1980). During lipid oxidation, malonaldehyde (MA), a minor component of fatty acids containing three or more double bonds, is formed as a result of the breakdown of polyunsaturated fatty acids. It is usually used as an indicator of the lipid oxidation process, both for the early appearance as oxidation occurs and for the sensitivity of the analytical method (Shahidi \& Zhong, 2005). 
TBA values of marinated samples increased significantly during storage $(p<0.01)$ (Fig. 4). Lower $(p<0.01)$ TBA values were found for sample $B$ compared to sample $A$ throughout storage. At the end of the retention period, TBA values of sample $B$ reached limit values, while sample $A$ exceeded the acceptable level. TBA value should be less than $3 \mathrm{mg}$ malonaldehyde/ $\mathrm{kg}$ in good quality material and not be more than $5 \mathrm{mg} / \mathrm{kg}$. The limit level is reported as $7-8 \mathrm{mg} / \mathrm{kg}$ by Schormüller (1968 \& 1969). Increases in TBA values have been reported for marinated anchovy (Gunsen et al., 2011), pacific saury (Sallam et al., 2007) and rainbow trout (Maktabi et al., 2015).

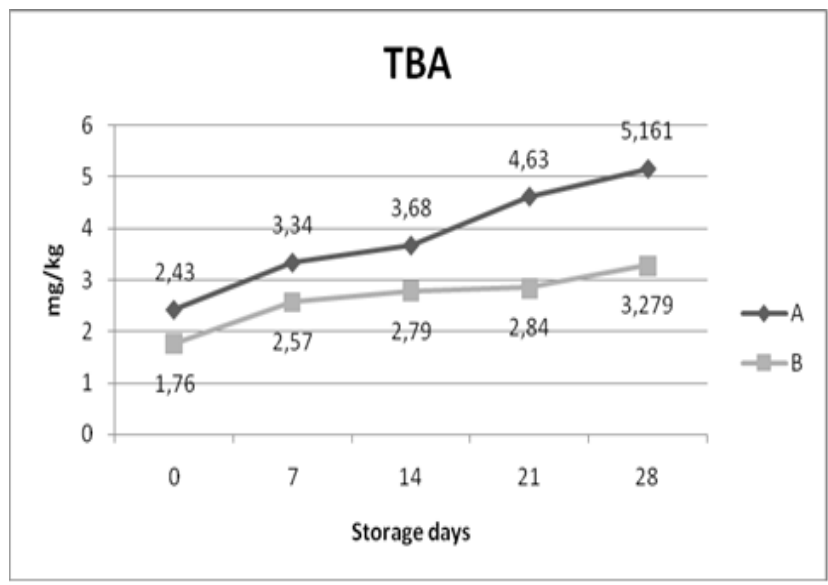

Figure 4. Thiobarbituric acid (TBA) values of marinated samples $\mathrm{A}$ (kept at $20^{\circ} \mathrm{C}$ ) and $\mathrm{B}$ (kept at $0^{\circ} \mathrm{C}$ ) during refrigerated storage

The initial para anisidine ( $\mathrm{p}-\mathrm{Av}$ ) value of the raw sample was found to be 6.81 . This value increased significantly $(p<0.01)$ after keeping at $20^{\circ} \mathrm{C}$ for $6 \mathrm{~h}$. However, the samples were kept unchanged at $0^{\circ} \mathrm{C}$ for $72 \mathrm{~h}$. After marinating, $\mathrm{p}$-Av increased significantly for both samples. Significant increases were observed during storage (Fig. 5).

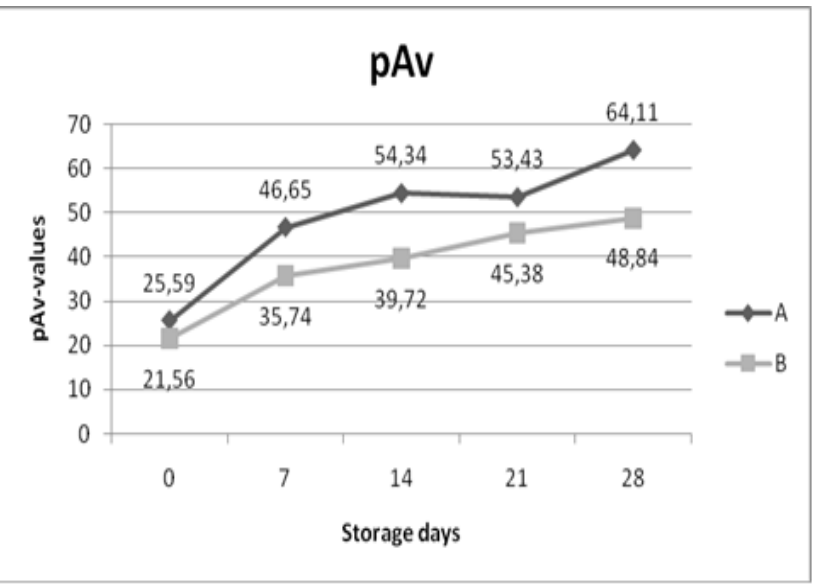

Figure 5. Para-anisidine (P-AV) values of marinated samples $A\left(\right.$ kept at $20^{\circ} \mathrm{C}$ ) and $B$ (kept at $0^{\circ} \mathrm{C}$ ) during refrigerated storage

At the end of storage, para-anisidine values of samples $A$ and $B$ were measured as 64.11 and 48.84 , respectively. The $p$ anisidine test provides useful information on non-volatile carbonyl compounds formed in oils during processing and is often used to detect secondary oxidation products. The paraanisidine value of good quality fish oil is reported to be less than 20 (Hamilton et al., 1998). In this study, para-anisidine values of marinated anchovy exceeded limit value. The increase in $p-A v$ of all samples indicates that primary lipid oxidation products (hydroperoxides), which may indicate an advanced stage of lipid oxidation, are significantly decomposed into secondary oxidation products (carbonyls). Higher $\mathrm{p}-\mathrm{Av}$ values were obtained in sample A compared to sample B. Raw material quality affected the oxidation level of marinated fish during storage.

Aerobic mesophilic count (APC) of raw fish was found to be $3.23 \mathrm{log} \mathrm{CFU} / \mathrm{g}$. Aerobic mesophilic counts were found as 4.30 and $4.04 \log \mathrm{CFU} / \mathrm{g}$ for the samples kept at $20^{\circ} \mathrm{C}$ and $0^{\circ} \mathrm{C}$ respectively. Keeping at ambient temperature caused a significant $(p<0.01)$ increase in APC. While the psychotropic count of raw fish was found as $3.78 \mathrm{log} \mathrm{CFU} / \mathrm{g}$, for samples kept at $20^{\circ} \mathrm{C}$ and $0^{\circ} \mathrm{C}$, it was determined as 3.59 and $3.82 \log \mathrm{CFU} / \mathrm{g}$, respectively. After marinating, microorganisms were not detected in marinated samples $A$ and $B$. Marinating the fish inhibited microorganisms due to their salt and acid content. The antimicrobial effect of acetic acid, especially bacteria and yeast, has been reported (Sen \& Temelli, 2003). In a previous study, microorganisms could not be isolated during the storage of marinated fish and it was reported that microorganisms were inhibited after marination (Erkan et al., 2000: Fuselli et al., 1994).

Sensory scores significantly $(p<0.01)$ decreased after keeping at $20^{\circ} \mathrm{C}$ and $0^{\circ} \mathrm{C}$. In sample $A$, a lower score was observed after $6 \mathrm{~h}$ at $20^{\circ} \mathrm{C}$ compared to sample B. Sensory scores of marinated fish decreased significantly $(p<0.01)$ during storage (Fig. 6). The decrease in sensory scores was faster in sample A than in sample B. After storage, the sensory score of sample $A$ reached the limit value of the deterioration. However, the score of example B was still within the limits of good quality.

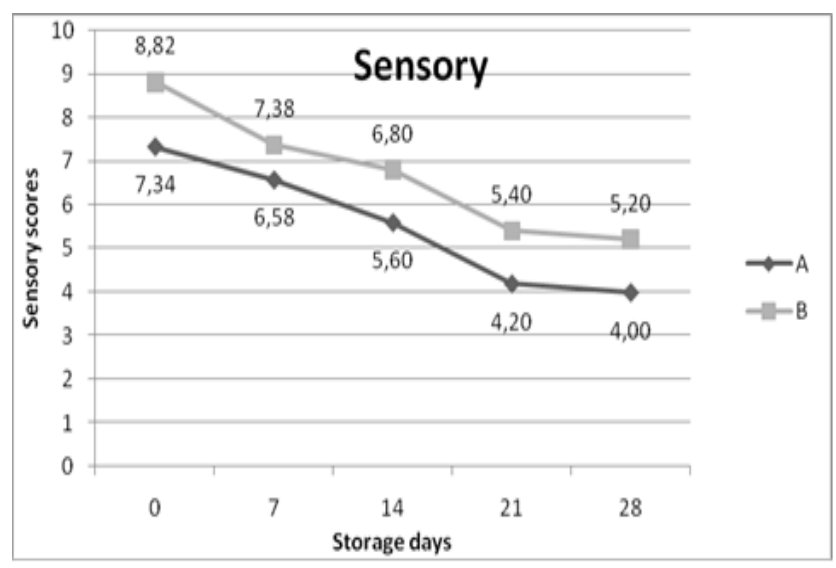

Figure 6. Sensory acceptability scores of marinated samples $A$ (kept at $20^{\circ} \mathrm{C}$ ) and $B$ (kept at $0^{\circ} \mathrm{C}$ ) during refrigerated storage.

\section{Conclusions}

The quality of fish products depends on the quality of raw material. Processing does not improve the quality of fish, protects only existing quality. It is accepted that organic acids used for marination extend the shelf-life of the product and provide safety. It is known that during marination, microbial activity is inhibited due to the combined activity of salt and acid solutions. Thus, it is believed that marination almost makes sterilization effect and therefore, the initial quality of fish is insignificant. The results of the present study clearly showed that the quality of raw material significantly affected the quality of the end product. Lower quality was observed in samples kept at $20^{\circ} \mathrm{C}$ during the storage. Especially lower sensory scores were found for this sample. For this reason, use of quality material should be a rule in fish processing operations. 


\section{Bibliography}

Aksu, H., Erkan, N., Colak, H., Varlik, C., Gokoglu, N., Ugur, M., 1997. Some changes in anchovy marinades during production in different acid-salt concentrations and determination of shelf life. The Journal of the Faculty of Veterinary Medicine University of Yuzuncu Yil, 8(1-2): 86-90.

Alasalvar, C., Grigor, J.M., Ali, Z., 2010. Practical evaluation of fish quality by objective, subjective and statistical testing. Handbook of Seafood Quality, Safety and Health Applications; Wiley-Blackwell; pp 13-28.

Amerina Ma, Pangborn Rv, Roessler EB., 1965. Principles of sensory evaluation of food; Academic Press, p. 602.

Anonymous., 1992. Compendium of methods for the microbiological examination of foods. American Publican Health Association, Washington D.C. USA.

Capaccioni, M.E., Casales, M.R., Yeannes, M.I., 2011. Acid and salt uptake during the marinatig process of Engraulis anchoita fillets influence of the solution:fish ratio and agitation. Ciência e Tecnologia de Alimentos, 31(4): 884-890.

Connell, J.J., 1980. Marinades. Control of Fish Quality (2nd edition), Scotland: Torry Research Station, Aberdeen, pp. 102-105.

El Marrackchi, A., Bennour, M., Bovchritt, N., Hamama, A., Tagafait, H., 1990. Sensory, chemical and microbiological assessments of Moroccan sardines (Sardina pilchardus) stored in ice. Journal of Food Protection, 53(7): 600-605.

Erkan, N., Metin, S., Varlik, C., Baygar, T., Ozden, O., Gun, H., Kalafatoglu, H., 2000. The effect of modified atmosphere packaging (MAP) on the shelf-life of marinated and breaded rainbow trout. Turkish Journal of Veterinary and Animal Sciences, 24 (6): 585-591.

Fuentes, A., Fernández-Segovia, I., Barat, J.M., Serrra, J.A., 2010. Physicochemical characterization of some smoked and marinated fish products. Journal of Food Processing and Preservation, 34: 83-103.

Fuselli, S.R., Casales, M.R., Fritz, R., Yeannes, M.I., 1994. Microbiology of the marination process used in anchovy (Engraulisanchiota) production. Lebensmittel Wissenschaft und Technologie, 27: 214-218.

Gokoglu, N., Cengiz, E., Yerlikaya, P., 2004. Determination of the shelf life of marinated sardine (Sardina pilchardus) stored at $4^{\circ} \mathrm{C}$. Food Control, 15 (1):1-4.

Gokoglu, N., Topuz, O.K., Yerlikaya, P., 2009. Effects of pomegranate sauce on quality of marinated anchovy during refrigerated storage. Lebensmittel Wissenschaft und Technologie, 42: 113-118.

Gunsen, U., Ozcan, A., Aydin, A., 2011. Determination of some quality criteria of cold storaged marinated anchovy under vacuum and modified atmosphere conditions.
Turkish Journal of Fisheries and Aquatic Sciences, 11: 233-242.

Hamilton, R. H., Kalu, C., McNeill, G. P., Padley, F. B., and Pierce, J. H., 1998. Effects of tocopherols, ascorbyl palmitate, and lecithin on autoxidation of fish oil. J. Am. Oil Chem. Soc., 75(7): 813-822.

IUPAC (International Union of Pure and Applied Chemistry), 1987. Method Number 2.504. Determination of the $p$ anisidine value $(P-A v)$. In: Standard Methods for the Analysis of Oils, Fats and Derivates. Blackwell Scientific Publications, Oxford, UK. pp. 143-144.

Ludorf, W., Meyer, V., 1973. Fische und Fischereierzeugnisse, Paul Parey Verlag, Hamburg, Berlin.

Maktabi, S., Zarei, M., Chadorbaf, M., 2015. Effect of traditional marinating on bacterial and chemical characteristics in frozen rainbow trout fillet. Journal of Food Quality and Hazards Control, 2: 128-133.

Manthey, M., Karnop, G., Rehbein, H., 1988. Quality changes of European catfish (Silurus glanis) from warm water aquaculture during storage in ice. International Journal of Food Science and Technology, 23: 1-9.

Mclay, R., 1972. Marinades. Torry Advisory Note No: 56. Ministry of Agriculture, Fisheries and Food, Torry Research Station. Aberdeen.

Ozden, O., Baygar, T., 2003. Farkli paketleme yöntemlerinin marine edilmis baliklarin bazi kalite kriterleri uzerine etkisi. Turkish Journal of Veterinary and Animal Sciences, 27: 899-906. (in Turkish).

Pons-Sanchez-Cascado, S., Vidal-Carou, M.C., Marine-Font, A. And Veciana-Nogues, M.T., 2005. Influence of the freshness grade of rawfish on the formation of volatile and biogenic amines during the manufacture and storage of vinegar-marinated anchovies. Journal of Agriculture and Food Chemistry, 53: 8586-8592.

Sallam, Kh. I, Ahmed, A.M., Elgazzar, M.M., Eldaly, E.A., 2007. Chemical quality band sensory attributes of marinated Pacific saury (Cololabis saira) during vacuum packaged storage at $4^{\circ} \mathrm{C}$. Food Chemistry, 102: 1061-1070.

Schormuller, J., 1968. Handbuch der Lebensmittel Chemie. Band III 12 Teil Tierische Lebensmittel Eier, Fleisch, Buttermilsch; Springer-Verlag, Berlin, Heidelberg, pp. 1561-1584.

Schormuller, J., 1969. Handbuch der lebensmittelchemie (Band IV); Springer Verlag. Heidelberg, Berlin.

Sen, M.K.C., TemeLLI S., 2003. Microbiological and chemical qualities of marinated anchovy prepared with different vegetable additives and sauce. Revue De Medecine Veterinaire, 154(11): 703-707.

Shahidi, F., Zhong, Y., 2005. Lipid oxidation: Measurement method. Bailey's Industrial Oil and Fat Products; Sixth Edition, John Wiley \& Sons, Inc.; pp. 357-385. 
Shenderyuk, V.I., Bykowski, P.J., 1989. Salting and marinating of fish. Seafood: resources, nutritional composition and preservation; CRC Press, Inc.; Boca Raton, Florida.

Sikorski, Z.E., Kolakowska, A., Burt, J.R., 1990. Post-harvest biochemical and microbial changes. Seafood: resources, nutritional composition and preservation; CRC Press Inc., Boca Raton, Florida.

Tarladgis, B.G., Watts, B.M., Younathan, M.S., Dugan, L.J.R., 1960. A distillation method for the quantitative determination of malonaldehyde in rancid foods. Journal of American. Oil Chemists' Society, 37: 44-48.

Villareal, B.P., Pozo, R., 1990. Chemical composition and ice spoilage of albacore (Thunnus albacore). Journal of Food Science, 55(3): 678-682. 